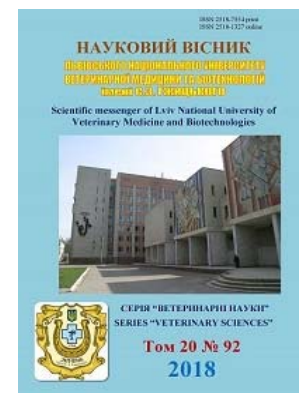

\author{
Науковий вісник Дьвівського національного університету \\ ветеринарної медицини та біотехнологій імені С.З. Гжицького
}

\author{
Scientific Messenger of Lviv National University \\ of Veterinary Medicine and Biotechnologies
}

ISSN 2518-7554 print

doi: $10.32718 /$ nvlvet9217

ISSN 2518-1327 online

http://nvlvet.com.ua

UDC 619:616.211-008.4:616.127-004:636.1

\title{
Treatment of horses with asthma syndrome complicated myocardiodystrophy
}

\author{
I. Maksymovych, L. Slivinska
}

Stepan Gzhytskyi National University of Veterinary Medicine and Biotechnologies Lviv, Ukraine

Article info

Received 18.10.2018

Received in revised form 20.11 .2018

Accepted 21.11.2018

Stepan Gzhytskyi National University of Veterinary Medicine and Biotechnologies Lviv,

Pekarska Str., 50, Lviv, 79010,

Ukraine.

Tel.: +38-097-290-95-02

E-mail:maksymovych@lvet.edu.ua
Maksymovych, I., \& Slivinska, L. (2018). Treatment of horses with asthma syndrome complicated myocardiodystrophy. Scientific Messenger of Lviv National University of Veterinary Medicine and Biotechnologies, 20(92), 83-93. doi: 10.32718/nvlvet9217

It has been established that in comorbid (cardiopulmonary) pathology in horses with asthma patients develop a syndrome of airway obstruction, morphofunctional changes in the erythrocyte system, impaired blood gas transmission function, increased permeability of cell membranes, which leads to complications in the form of myocardiodystrophy and cardiac failure. The use of a complex treatment regimen for horses with asthma and complicated myocardiodystrophy contributed to reducing attacks of respiratory dysfunction and symptoms of heart failure, reducing the incidence of arrhythmias and valvular regurgitation, reducing the number of neutrophils in the BAL washings, and reducing indicators characteristic of tissue hypoxia, (decrease in the number of erythrocytes, hemoglobin, hematocrit, mean corpuscular volume and mean corpuscular hemoglobin), elimination of the inflammatory process in the respiratory tract (decrease in the number of leukocytes, stab and segmented neutrophils), a decrease in the indices characterizing the integrity of the cardiomyocyte membranes (decrease in the activity of $C K, C K-M B, L D H, L D H-1$ ), restoration of diffuse capacity of the lungs (decrease in $\mathrm{pH}$ and increase in $\mathrm{pO} 2$ and $\mathrm{pCO} 2$ of blood). The mechanism of the positive effect of drugs that were used to treatment of horses with asthma syndrome with complicated myocardiodystrophy, which is achieved due to the cardio metabolic (cytoprotective) effect and antihypoxic ability to improve the diffusion of gases through the alveolar-capillary membrane, is established. On the one hand, it improves metabolic processes in the myocardium and, accordingly, reduces the manifestations of heart failure, and on the other hand, reduces hypoxia and respiratory failure (respiratory dysfunction), as one of the central pathogenetic mechanisms of cardiorespiratory comorbidity.

Key words: cardiopulmonary syndrome, equine asthma syndrome, myocardiodystrophy, comorbid pathology, bronchodilators, metabolic therapy.

\section{Лікування коней, хворих на астму, ускладнену міокардіодистрофісю}

\author{
І.А. Максимович, Л.Г. Слівінська
}

Львівський національний університет ветеринарної медицини та біотехнологій імені С.3. Гжицького, м. Львів, Україна

Встановлено, щчо при коморбідній (кардіо-пульмональній) патологї у коней, хворих на астму, розвивається симптомокомплекс обструкиї дихальних иляхів, морфофункціональні зміни еритроцитарної системи, порушення газотранспортної функиії крові, підвищення проникності клітинних мембран, щуо призводить до ускладнень у формі міокардіодистрофії та розвитку сериевої недостатності. Застосування комплексної схеми лікування коней, хворих на астму, ускладнену міокардіодистрофією, сприяло зменшенню приступів респіраторної дисфункцї та симптомів сериевої недостатності, зменшенню частоти виникнення аритмій та клапанної регургітації, зменшенню кількості нейтрофілів у змивах БАЛ, зниженню показників, цуо характерні для тканинної гіпоксї (зменшення кількості еритроцитів, вмісту гемоглобіну, величини гематокриту, середнього об'єму еритроцита та середнього вмісту гемоглобіну в еритроциті), усуненню запального процесу в дихальних шляхах (зменшення кількості лейкоцитів, паличкоядерних і сегментоядерних нейтрофілів), зниженню показників, щцо характеризують иілісність мембран кардіоміоцитів (зниження активності КК, КК-МВ, ЛДГ, ЛДГ-1), відновленню дифузної здатності легень (зниження рН та підвищення рО2 і рСО2 крові). Встановлено механізм позитивного впливу препаратів, які використовувалися для лікування коней, хворих на астму, ускладнену міокардіодистрофією, шо досягається за рахунок кардіометаболічного (цитопротективного) ефекту й антигіпоксичної здатності поліпшувати дифузію газів через альвеолярно-капілярну мембрану. Це, з одного боку, поліпшує процеси метаболізму в міокарді і відповідно зменшує прояви сериевої недостатності, а з іншого - зменшує гіпоксію та прояви дихальної недостатності (респіраторної дисфункиії), як одного з иентральних патогенетичних механізмів формування кардіо-респіраторної коморбідності. 
Ключові слова: кардіо-пульмональний синдром, астма коней, міокардіодистрофія, коморбідна патологія, бронходилататори, метаболічна терапія.

\section{Вступ}

Респіраторні захворювання у коней $є$ основною причиною виключення їх з робочого, спортивного чи рекреаційного використання, оскільки саме дихальна система лімітує їхню фізичну працездатність (Sánchez et al., 2005; Maksymovych et al., 2016).

У хворих на астму коней за рахунок обструкції дихальних шляхів розвиваються симптоми дихальної недостатності (Niedźwiedź et al., 2006), яка супроводжується патологічними змінами у серцево-судинній системі (Pasławska et al., 2008; Maksymovych, 2015).

Хронічна серцева недостатність (ХCH) є проблемою у хворих на хронічні обструктивні захворювання легень (ХОЗЛ) (Palomo et al., 2006). Діагностика ХCH при ХОЗЛ становить певні труднощі, оскільки вона маскується проявами гострої чи хронічної дихальної недостатності або бронхообструктивним синдромом (Ollivier et al., 2007). За поєднаного перебігу дихальної та серцевої недостатності прогноз тривалості життя хворих є несприятливим (Falk et al., 2008).

Різноманітні порушення метаболізму, що формуються при коморбідній (кардіо-пульмональній) патології, здатні призводити до електричної нестабільності міокарда та розвитку аритмій, зокрема й фатальних. Хронічна гіпоксія, що розвивається при ХОЗЛ, значно наростає при ускладненні ХСН як стресовий чинник, ускладнює перебіг, підсилює режими функціонування основних систем i органів, насамперед міокарда (Avdeev and Bajmakanova, 2008). Системну гіпоксію можна вважати основним чинником, що обумовлює порушення функцій серця, оскільки вона реалізує свій негативний вплив і через ряд опосередкованих ланок патогенезу (Ambrosino and Simonds, 2007). Гіпоксія індукує синтез прозапальних медіаторів (Korzh, 2008), виступає стимулятором активації синтезу тромбоксану А2, що в поєднанні 3 підвищенням показників гематокриту викликає мікроциркуляторні порушення в міокарді й малому колі кровообігу, сприяє розвитку коронароспазму, дистрофії міокарда, прогресуванню $\mathrm{XCH}$, які при ХОЗЛ часто маскуються клінічними проявами респіраторної патології (Chuchalin, 2008; Maksymovych, 2017).

Маловивченим є зв'язок між респіраторною недостатністю, що розвивається у хворих на ХОЗЛ, дисфункцією міокарда й виникненням шлуночкових аритмій (Falk et al., 2008). Діастолічна дисфункція лівого шлуночка $є$ чинником, що сприяє розвитку шлуночкових аритмій. У клінічній практиці рекомендується проводити детальнішу діагностичну оцінку епізодів шлуночкових порушень ритму, що виникли на тлі саме діастолічної дисфункції, оскільки за цими проявами може бути прихована хронічна ішемія міокарда, гібернація міокарда, формування легеневого серця (Chuchalin, 2008). До того ж, функція діастоли лівого шлуночка серця вважається найбільш чутливим маркером ішемії міокарда, толерантності до фізичних навантажень і має важливе значення у визначенні клінічного статусу та прогнозу при ХCH (Korzh, 2008).

Існує й ціла низка проблем, пов'язаних із призначенням препаратів, що застосовують у терапії таких коморбідних захворювань, як ХОЗЛ і ХСН. Так, призначення бета-адреноблокаторів супроводжується, 3 одного боку, позитивним впливом на якість і тривалість життя при ХСН, а з іншого - погіршенням стану бронхіальної провідності (Ollivier et al., 2007).

Найважливішим у фармакологічній терапії за астми $\epsilon$ усунення запального процесу в дихальних шляхах, зняття бронхоспазму та застосування метаболічних препаратів, здатних відновлювати клітинний метаболізм, іонний гомеостаз та функції мембран клітин серця, попереджаючи, або зменшуючи розвиток незворотних процесів (Capko et al., 2016).

Для лікування астми в коней застосовують кортикостероїди системної, або місцевої дії, бронходилататори, що знижують тонус гладких м'язів бронхів і усувають їх спазм, тобто зменшують прояви синдрому бронхообструкції. 3 цієї групи застосовують антихолінергічні препарати (холінолітики), b2адреноміметики (Duvivier et al., 1997; Duvivier et al., 1999). Правильний підбір препаратів, систематична i довготривала терапія визначає ефективне лікування хворих тварин (Robinson et al., 2002).

Обов'язковим компонентом терапії астми, ускладненої серцевою недостатністю, є застосування препаратів, дія яких спрямована на відновлення та стабілізацію метаболізму міокарда (Amosova, 2000).

Як відомо, цитопротективні засоби поліпшують енергетичний метаболізм міокарда шляхом прямої модуляції окислювальних процесів у кардіоміоцитах (Schraeder et al., 2005; Sin et al., 2006). Теоретичний сенс застосування метаболічних засобів полягає в активізації менш “кисневмісного” порівняно з окисленням жирних кислот шляху енергопродукції, а саме окислення глюкози (аеробний та анаеробний гліколіз) (Palomo et al., 2006; Boudestein et al., 2009).

Незважаючи на велику кількість робіт із дослідження поєднаного перебігу ХОЗЛ і ХСН, недостатньо вивченими залишаються питання патогенезу, факторів взаємного обтяження та ефективного лікування хворих з такою сукупною (коморбідною) кардіо-респіраторною патологією (Ihnatenko et al., 2011).

Метою роботи було вивчити ефективність лікування коней, хворих на астму, ускладнену міокардіодистрофією (МКД).

\section{Матеріал і методи досліджень}

Матеріалом для досліджень були спортивні та робочі коні української верхової, ганноверської, вестфальської, торійської порід і безпородні тварини.

Дослідження проводили на 23 тваринах: 10 коней хворих на астму ускладнену МКД (дослідна група) віком від 7 до 22 років $(13,0 \pm 1,54)$, масою тіла $450,0 \pm 30,42$ кг (350,0-690,0) і 13 клінічно здорових 
тварин (контрольна група) віком від 6 до 14 років $(9,1 \pm 0,80)$, масою тіла 463,4 $\pm 26,15$ кг $(370,0-660,0)$.

В усіх коней проводили клінічні та лабораторні дослідження, виконували ляринготрахеобронхоскопію, бронхоальвеолярний лаваж (БАЛ), електрокардіографію і ехокардіографію (ЕхоКГ), аналізували умови утримання та годівлі тварин.

Комплекс клінічних та інструментальних досліджень виконували до лікування і через 10 днів після його завершення. Коней досліджували клінічно: вимірювали внутрішню температуру тіла, підраховували частоту дихання, підраховували частоту та аналізували якість артеріального пульсу, вислуховували серце, оцінювали колір слизових оболонок і час наповнення капілярів, досліджували венний пульс.

Аускультацію серця проводили в місцях найкращого вислуховування клапанів (puncta optima, p.opt.). Звертали увагу на силу, тембр, чіткість та ритм серцевих тонів; наявність шумів, їх локалізацію, відношення до фази серцевої діяльності, час появи, характер, інтенсивність, тривалість.

Діагноз на астму підтверджували за результатами ендоскопічного дослідження, використовуючи систему оцінки кількості трахеального слизу. У здорових коней допустиме виділення в трахеї не більше $1^{\circ}$ (Gerber et al., 2004).

У коней виконували цитологічне дослідження змивів $з$ нижніх дихальних шляхів, отриманих за допомогою бронхоальвеолярного лаважу (БАЛ), визначали тип та кількість лейкоцитів (нейтрофіли, лімфоцити, макрофаги, мастоцити, еозинофіли).

Електрокардіографію проводили за допомогою 3канального електрокардіографа "Кардіостиль ветеринарний” впродовж 5 хвилин при швидкості 50 мм/с, чутливості апарату $1 \mathrm{mB}$ (10 мм). Електрокардіограму (ЕКГ) реєстрували в стандартних (I, II, III) і посилених (aVR, aVL, aVF) відведеннях. Червоний електрод кріпили справа у яремному жолобі, жовтий - зліва за ліктьовим горбом, зелений - зліва на гребені лопатки, чорний електрод - спереду грудної клітки. Проводили аналіз ЕКГ в II відведенні, на основі чого діагностували аритмії.

Ехокардіографію (ЕхоКГ) і допплерографію серця виконанували на ультразвукових діагностичних приладах "MyLab Alpha", "MyLab 25 Gold" ("Esaote", Італія) 3 використанням секторних датчиків (2,53,0 МГц). ЕхоКГ проводили у В-режимі, імпульсній та постійнохвильовій доплерехокардіографії, виконували колірне картування потоку. Візуалізували анатомічну будову клапанів і рухливість стулок; оцінювали розміри порожнин серця, скоротливість; уточнювали тяжкість клапанної недостатності та ступінь вираженості стенозу.

Забір крові для загального аналізу та біохімічного дослідження проводили з яремної вени в пробірки $(2,0$ мл; Sarstedt, Німеччина) з антикоагулянтом (EDTA-K) та пробірки (10 мл; Vacutest, Італія) без антикоагулянта. Проби транспортували в термоконтейнері та аналізували протягом 6 годин від моменту відбору.

Загальний аналіз крові досліджували на автоматичному гематологічному аналізаторі Mythic 18 (Orphee
S.A., Швейцарія), використовуючи реагенти PZ Cormay S.A. (Польща).

У крові визначали кількість еритроцитів (RBC), вміст гемоглобіну $(\mathrm{Hb})$, величину гематокриту (PCV), середній об'єм еритроцита (MCV), середній вміст гемоглобіну в еритроциті (MCH), середню концентрацію гемоглобіну в еритроцитах (МСHC), ширину розподілу еритроцитів за об'ємом (RDW), відносну ширину розподілу еритроцитів за об'ємом (RDW-SD), кількість лейкоцитів (WBC), виводили лейкограму із диференціюванням різних форм лейкоцитів (еозинофіли, базофіли, нейтрофіли, моноцити, лімфоцити), кількість тромбоцитів (PLT), тромбокрит (PCT), середній об'єм тромбоцитів (MPV), ширину розподілу тромбоцитів за об'ємом (PDV).

Для отримання сироватки крові пробірки центрифугували при 3000 об/хв протягом 10 хв. Вивчали функціональний стан печінки за вмістом у сироватці крові загального протеїну, альбумінів, загального білірубіну; нирок за концентрацією сечовини та креатиніну; вуглеводний обмін за вмістом глюкози; обмін макроелементів і електролітів аналізували за вмістом загального кальцію, неорганічного фосфору, магнію, феруму, натрію та калію.

В сироватці крові досліджували активність аспартатамінотрансферази (АсАТ), аланінамінотрасферази (АлАТ), лужної фосфатази (ЛФ), гаммаглутамілтранспептидази (ГГТП), загальної креатинкінази (КК) та їі серцевого ізоферменту (КК-МВ), загальної лактатдегідрогенази (ЛДГ) та ЛДГ-1 (гідроксибутиратдегідрогеназа) за допомогою автоматичного біохімічного аналізатора Mindray BS-120 (Китай), використовуючи реагенти PZ Cormay S.A. (Польща).

Вміст калію та натрію в сироватці крові коней визначали на напівавтоматичному біохімічному аналізаторі BioChem SA (США), використовуючи реактиви High Technology Inc., Production RD Walpole (США).

Для дослідження показників кислотно-основного балансу (КОБ) артеріальну кров відбирали анаеробно в гепаринізовані шприци пункцією лицевої артерії використовуючи катетери $20 \mathrm{G}$ для ін'єкцій типу “метелик”. Дослідження проб крові проводили відразу після відбору та аналізували рН (водневий показник), $\mathrm{pCO}_{2}$ (парціальний тиск вуглекислого газу), $\mathrm{pO}_{2}$ (парціальний тиск кисню) на автоматичному газовому аналізаторі OPTI CCA-TS (OPTI Medical Systems, Inc., Roswell, GA, USA).

Схема лікування коней, хворих на астму, ускладнену міокардіодистрофією, включала:

1. Дексаметазон - 0,04 мг/кг в/м, один раз/добу, 3 ін'єкції з інтервалом 48 год.

2. Ventolin $\AA$ (діюча речовина сальбутамол) 500 мкг/тварину (5 доз) інгаляційно, 4 рази/добу, перших 3 дні.

Atrovent ${ }^{\circledR}$ (діюча речовина іпратропію бромід) 200 мкг/тварину (10 доз) інгаляційно, 2 рази/добу, наступних 5 днів.

3. Кокарбоксилаза - 60 мл в/в, 1 раз/добу, 6 днів.

4. Роборанте Калієр - 20,0 мл підшкірно, 1 раз/добу, 6 днів. 
5. Ронколейкін - $10000 \mathrm{MO} /$ кг (500 тис МО/гол) п/шк (в середній третині шиї), 3 рази 3 інтервалом 48 год. Вміст ампули розводили в 10 мл $0,9 \% \mathrm{NaCl}$.

Критеріями ефективності лікування коней хворих на астму ускладнену МКД, були: зменшення або відсутність нападів кашлю, носових виділень; відсутність трахеального слизу (не більше ніж $1^{\circ}$ ); зменшення кількості нейтрофілів у змивах БАЛ; нормалізація частоти пульсу та дихання; нормалізація морфологічних і біохімічних показників та КОБ крові; зменшення частоти аритмій та клапанної регургітації; збільшення толерантності до фізичних навантажень та відновлення працездатності.

Математичну обробку отриманих результатів проводили з використанням програмного забезпечення Microsoft Office Excel за допомогою загальноприйнятих методів варіаційної статистики 3 оцінкою середнього (М), його похибки (m), вірогідність встановлювали за t-критерієм Стьюдента.

\section{Результати та їх обговорення}

Астма коней ускладнена міокардіодистрофією, або кардіо-пульмональний синдром характеризувалася розвитком приступів респіраторної дисфункції та симптомами серцевої недостатності.

У хворих на астму коней, ускладнену МКД, реєстрували кашель, слизові та слизисто-гнійні носові виділення (найчастіше зранку та під час навантаження чи тренування), зниження працездатності.

Температура тіла у хворих коней в середньому становила $37,8 \pm 0,08{ }^{\circ} \mathrm{C}\left(37,5-38,2{ }^{\circ} \mathrm{C}\right)$, частота пульсу $-40,7 \pm 1,95$ уд/хв (29-56), частота дихання $18,5 \pm 1,50$ дих. рух/хв (10-25). У 40\% хворих коней реєструвалася тахікардія, а у 50\% - тахіпное. В однієї тварини за астми, ускладненої МКД, виявлено ціаноз слизових оболонок.

За коморбідної (астма, ускладнена МКД) патології реєструвалося стійке диспное. Під час нападів астми в хворих коней змінювалася частота (тахіпное), ритм (переривчасте дихання) і глибина дихання. У хворих коней розвивався симптомокомплекс обструкції дихальних шляхів (задишка, розширення крил носа, черевний тип дихання, западання міжреберних просторів, двоступеневий видих).

Під час аускультації легень зміни в стані спокою були відсутні. Після навантаження прискорене дихання супроводжувалося крепітацією по всій поверхні легенів і хрипами у діафрагмальних долях. За важкого перебігу хрипи реєстрували над усім полем легень, а задня межа зміщувалася каудально.

Ознаками серцевої недостатності були: ціаноз слизових оболонок, зниження вгодованості, прискорений, слабкий та неритмічний пульс, втомлюваність, збільшення часу відновлення після навантаження.

Серцевий поштовх у 20\% хворих коней був посилений, у 40\% - послаблений. У 20\% хворих тварин реєстрували розщеплення першого серцевого тону та ще у $20 \%$ - акцентування другого тону на легеневій артерії.

У 70\% хворих на астму коней, ускладнену МКД, при аускультації діагностували серцеві шуми. Систо- лічний шум в p.opt. мітрального клапана вислуховували у 2/20\% коней, клапанів аорти - у 1/10\% тварини, над легеневою артерією - у 2/20\% коней. Діастолічний шум в p.opt. клапанів аорти реєстрували в $2 / 20 \%$ тварин. В контрольній групі систолічний шум в p.opt. мітрального клапана вислуховували у 2/15,38\% коней, клапанів аорти - у 1/7,69\%, над легеневою артерією - у 1/7,69\% тварини. Діастолічний шум в p.opt. клапанів аорти реєстрували в 2/15,38\% тварин, що складає в загальному 46,15\% (6 тварин) від контрольної групи коней.

При ендоскопії у хворих на астму коней в трахеї та головних бронхах візуалізували слизові та слизистогнійні виділення $2^{\circ}$ і вище ступеня, а в цитологічних препаратах, отриманих за допомогою БАЛ виявляли змішану популяцію клітин, найбільшою кількісною групою з яких були нейтрофіли (40,2 \pm 5,37\%; 35-87). В тварин контрольної групи нейтрофілів у змивах БАЛ було в середньому 6,2 $\pm 0,36 \%$ (3-8\%; P < 0,001).

За результатами електрокардіографії, проведеної в хворих коней встановлено, що у 6 тварин (60\%) ритм був синусовий, у 2 коней (20\%) реєстрували синусову аритмію, в 4 (40\%) - тахікардію, в 1 (10\%) - атріовентрикулярну (AB) блокаду II ступеня та суправентрикулярну екстрасистолію, що складає 70\% від дослідної групи тварин. В контрольній групі ритм був синусовий у 10 тварин (76,92\%), у 2 коней (15,38\%) діагностували синусову аритмію, в 1 (7,69\%) - тахікардію, у 1 (7,69\%) - атріовентрикулярну (АВ) блокаду II ступеня (30,77\% від контрольної групи коней).

За результатами ехокардіографії у 5/50\% коней, хворих на астму ускладнену МКД, діагностували клапанну регургітацію (мітрального клапана - 2/20\%, клапанів аорти - 2/20\%, клапанів легеневої артерії $1 / 10 \%$ ), тоді як у коней контрольної групи - у 4/30,77\% тварин (мітрального клапана - 1/7,69\%, клапанів аорти - 2/15,38\%, клапанів легеневої артерії $-1 / 7,69 \%)$.

У коней за астми, ускладненої МКД, вивчали морфофункціональний стан еритроцитарної системи (середній об'єм, середній вміст і концентрацію гемоглобіну в еритроциті, цитоархітектоніку червоних клітин крові). Деталізація даних про патогенетичне значення змін в системі еритрона $є$ передумовою до створення науково-обгрунтованих методів їхньої корекції (Glazova et al., 2012).

В ході дослідження виявлено відхилення морфофункціональних характеристик еритроцитарної системи. Так, у коней, хворих на астму, ускладнену МКД, збільшувалася кількість еритроцитів $(\mathrm{P}<0,05)$, вміст гемоглобіну $(\mathrm{P}<0,001)$ та гематокрит $(\mathrm{P}<0,01)$, порівняно з клінічно здоровими тваринами (табл. 1). Підвищеними також були індекси червоної крові, зокрема середній об'єм еритроцита $(\mathrm{P}<0,001)$ та середній вміст гемоглобіну в еритроциті $(\mathrm{P}<0,001$; табл. 1). Високі показники кількості еритроцитів і концентрації гемоглобіну з'являються при розвитку недостатності зовнішнього дихання.

Зі спеціалізованої літератури відомо, що у хворих на ХОЗЛ ширина розподілу еритроцитів за об'ємом (RDW) може збільшуватися тоді, коли зростає ступінь анізацітозу, зокрема, при регенераторних анеміях за 
рахунок ретикулоцитів і молодих еритроцитів, при ферумдефіцитній анемії (у фазі, коли еритроцити мають ще нормальну а також змінену величину). Як і при визначенні середнього об'єму еритроцита (MCV), кількість великих еритроцитів в крові має досягти певного рівня, щоб RDW вийшло за межі стандартних коливань. Лише в окремих випадках RDW збільшується раніше ніж MCV. У міру розвитку відповідної реакції тварини на анемію незрілі еритроцити стають переважаючими, величина RDW починає знижуватися навіть при ще високому значенні MCV. Показник RDW характеризує коливання об'єму клітин усередині популяції і не пов'язаний з абсолютною величиною об'єму еритроцитів. Причинами низького рівня RDW в крові можуть бути також патологічні стани, які призводять до втрати біологічних функцій еритроцитів (Nowak et al., 2005). Отже, за астми ускладненої МКД виникають передумови до розвитку анемії, оскільки величина RDW у хворих коней була вірогідно меншою (Р $<0,001)$, порівняно з клінічно здоровими тваринами (табл. 1).

Запальний процес за астми коней ускладненої МКД супроводжувався збільшенням кількості лейкоцитів ( $<<0,001)$, паличкоядерних та сегментоядерних нейтрофілів $(\mathrm{P}<0,001)$ і зсувом лейкоцитарної формули вліво, тоді як кількість лімфоцитів зменшувалася (Р $<0,001 ;$ табл. 2).

У крові хворих коней зменшеною була кількість тромбоцитів $(\mathrm{P}<0,05)$ і величина тромбокриту $(\mathrm{P}<$ 0,01 ; табл. 3), що, очевидно, пов'язано із активацією тромбопоезу та поглибленням змін в дихальних шляхах, які сприяють їх ремоделюванню та бронхоконстрикції (Pitchford et al., 2004).

Таблиця 1

Показники еритропоезу в коней хворих на астму ускладнену МКД

\begin{tabular}{|c|c|c|c|}
\hline Показники & $\begin{array}{l}\text { Клінічно здорові коні } \\
\mathrm{n}=13\end{array}$ & $\begin{array}{c}\text { Хворі коні } \\
\mathrm{n}=10\end{array}$ & $\begin{array}{c}\text { Після лікування } \\
\mathrm{n}=10\end{array}$ \\
\hline \multirow[t]{2}{*}{ Еритроцити (RBC), T/л } & $7,5 \pm 0,20$ & $9,0 \pm 0,53 *$ & $7,7 \pm 0,32^{\circ}$ \\
\hline & $6,0-8,3$ & $6,8-11,8$ & $6,3-8,5$ \\
\hline \multirow[t]{2}{*}{ Гемоглобін (Нb), г/л } & $118,3 \pm 3,50$ & $149,8 \pm 6,70 * * *$ & $120,7 \pm 4,48^{\circ \circ}$ \\
\hline & $92,0-132,0$ & $113,0-186,0$ & $96,0-142,0$ \\
\hline \multirow[t]{2}{*}{ Гематокрит (PCV), \% } & $31,8 \pm 0,89$ & $39,4 \pm 2,23 * *$ & $32,0 \pm 1,40^{\circ}$ \\
\hline & $26,5-35,4$ & $30,0-51,9$ & $26,0-40,0$ \\
\hline \multirow{2}{*}{ Середній об’єм еритроцита (MCV), фл } & $42,5 \pm 0,41$ & $45,9 \pm 0,67 * * *$ & $42,3 \pm 0,50^{\circ 0 \circ}$ \\
\hline & $39,8-44,4$ & $43,8-49,5$ & $39,4-43,5$ \\
\hline \multirow{2}{*}{$\begin{array}{l}\text { Середній вміст гемоглобіну в еритроциті (МСН), } \\
\text { пг }\end{array}$} & $15,8 \pm 0,11$ & $17,5 \pm 0,21 * * *$ & $16,0 \pm 0,19^{\circ \circ \circ}$ \\
\hline & $15,3-16,3$ & $16,4-18,4$ & $15,1-17,0$ \\
\hline Середня концентрація гемоглобіну в еритроцитах & $37,3 \pm 0,31$ & $37,8 \pm 0,31$ & $37,0 \pm 0,35$ \\
\hline (МСНC), г/дл & $34,5-38,5$ & $35,8-38,9$ & $34,1-38,6$ \\
\hline Ширина розподілу еритроцитів за об'ємом & $20,8 \pm 0,08$ & $18,9 \pm 0,26^{* * *}$ & $20,0 \pm 0,22^{\circ \circ}$ \\
\hline$(\mathrm{RDW}), \%$ & $19,3-21,2$ & $17,0-19,6$ & $18,0-21,0$ \\
\hline Відносна ширина розподілу еритроцитів за & $31,8 \pm 0,47$ & $32,8 \pm 0,58$ & $32,0 \pm 0,52$ \\
\hline об’ємом (RDW-SD), фл & $29,0-33,5$ & $30,3-35,5$ & $29,3-34,5$ \\
\hline
\end{tabular}

\section{Таблиця 2}

Показники лейкопоезу в коней хворих на астму ускладнену МКД

\begin{tabular}{lccc}
\hline \multicolumn{1}{c}{ Показники } & Клінічно здорові коні & Хворі коні & Після лікування \\
\hline \multirow{2}{*}{ Лейкоцити (WВС), Г/л } & $6,9 \pm 0,29$ & $10,4 \pm 0,55^{* * *}$ & $7,1 \pm 0,50^{\circ \circ \circ}$ \\
\multirow{2}{*}{ Еозинофіли, \% } & $5,1-8,8$ & $7,5-13,7$ & $5,7-10,0$ \\
\multirow{2}{*}{ Базофіли, \% } & $2,5 \pm 0,53$ & $3,9 \pm 0,86$ & $2,8 \pm 0,54$ \\
& $0-5$ & $1-10$ & $1-6$ \\
Паличкоядерні нейтрофіли, \% & $0,7 \pm 0,11$ & $1,3 \pm 0,50$ & $1,0 \pm 0,26$ \\
& $0-1$ & $0-4$ & $0-3$ \\
Сегментоядерні нейтрофіли, \% & $1,4 \pm 0,43$ & $5,7 \pm 0,92^{* * *}$ & $2,0 \pm 0,40^{\circ \circ}$ \\
& $0-4$ & $3-12$ & $0-4$ \\
Моноцити, \% & $38,6 \pm 2,09$ & $49,7 \pm 1,82^{* * *}$ & $40,2 \pm 1,77^{\circ \circ}$ \\
\multirow{2}{*}{ Лімфоцити, \% } & $28-49$ & $41-61$ & $31-48$ \\
& $2,6 \pm 0,27$ & $3,3 \pm 0,45$ & $2,5 \pm 0,32$ \\
\hline \hline
\end{tabular}


Таблиця 3

Показники тромбопоезу в коней хворих на астму ускладнену МКД

\begin{tabular}{lccc}
\hline \multicolumn{1}{c}{ Показники } & Клінічно здорові коні & Хворі коні & Після лікування \\
\hline Тромбоцити (РLT), & $159,5 \pm 27,19$ & $83,0 \pm 10,45^{*}$ & $128,4 \pm 11,44^{\circ}$ \\
Г/л & $54,0-338,0$ & $50,0-129,0$ & $69,0-170,0$ \\
Тромбокрит (РСТ), & $0,082 \pm 0,0115$ & $0,044 \pm 0,0050^{* *}$ & $0,067 \pm 0,0090^{\circ}$ \\
\% & $0,029-0,142$ & $0,028-0,067$ & $0,020-0,121$ \\
Середній об'єм тромбоцитів & $5,4 \pm 0,15$ & $5,5 \pm 0,08$ & $5,5 \pm 0,14$ \\
(МРV), фл & $4,2-5,8$ & $5,0-5,9$ & $4,6-6,0$ \\
Ширина розподілу тромбоцитів & $81,1 \pm 1,73$ & $78,2 \pm 1,15$ & $79,8 \pm 1,54$ \\
за об'ємом (PDV), \% & $70,9-90,3$ & $71,2-78,2$ & $69,0-88,3$ \\
\hline
\end{tabular}

Таблиця 4

Біохімічні показники сироватки крові коней хворих на астму ускладнену МКД

\begin{tabular}{ccccccc}
\hline Показники & $\begin{array}{c}\text { Загальний протеїн, } \\
\text { г/л }\end{array}$ & $\begin{array}{c}\text { Альбуміни, } \\
\text { г/л }\end{array}$ & $\begin{array}{c}\text { Загальний білірубін, } \\
\text { мкмоль/л }\end{array}$ & $\begin{array}{c}\text { Глюкоза, } \\
\text { ммоль/л }\end{array}$ & $\begin{array}{c}\text { Сечовина, } \\
\text { ммоль/л }\end{array}$ & $\begin{array}{c}\text { Креатинін, } \\
\text { мкмоль/л }\end{array}$ \\
\hline Клінічно & $61,6 \pm 0,85$ & $36,9 \pm 0,56$ & $20,1 \pm 1,18$ & $5,8 \pm 0,17$ & $5,3 \pm 0,20$ & $126,6 \pm 4,60$ \\
здорові коні & $57,8-69,3$ & $33,7-39,4$ & $15,3-27,5$ & $4,8-6,6$ & $4,5-6,5$ & $88,5-143,4$ \\
Хворі коні & $69,9 \pm 1,67 * * *$ & $38,6 \pm 0,92$ & $22,5 \pm 2,49$ & $5,1 \pm 0,20 *$ & $4,9 \pm 0,20$ & $121,7 \pm 4,54$ \\
Після & $57,5-75,9$ & $35,8-45,9$ & $7,5-31,54$ & $4,0-6,1$ & $4,2-6,0$ & $100,9-152,4$ \\
лікування & $64,0 \pm 1,40^{\circ}$ & $38,1 \pm 0,70$ & $20,9 \pm 1,87$ & $5,6 \pm 0,18$ & $5,0 \pm 0,19$ & $124,9 \pm 5,01$ \\
& $58,5-75,1$ & $35,1-41,7$ & $10,7-28,3$ & $4,5-6,3$ & $4,3-6,3$ & $91,5-150,7$ \\
\hline
\end{tabular}

У коней, хворих на астму, ускладнену МКД в сироватці крові зростав вміст загального протеїну ( $<<0,001$; табл. 4), що, очевидно, є результатом запальної реакції в дихальних шляхах, тимчасом як альбуміни не відрізнялися від показників клінічно здорових тварин. У крові хворих коней нами встановлено тенденцію до підвищення концентрації білірубіну, тимчасом як вміст глюкози вірогідно знижувався ( $<<0,05$; табл. 4).

В сироватці крові хворих коней встановлено тенденцію до зниження концентрація сечовини та креатиніну, проте їх ліміти не виходили за межі фізіологі- чних коливань (табл. 4). Отже, за поєднаного перебігу астми та міокардіодистрофії у хворих коней не порушувався функціональний стан нирок.

У коней, хворих на астму, ускладнену МКД, в сироватці крові зростала активність АсАТ (Р < 0,05; табл. 5), що, очевидно, пов'язано з порушенням проникності мембран м'язових клітин, у тому числі кардіоміоцитів та розвитку синдрому цитолізу (Singh et al., 2011). Активність АлАТ в крові хворих коней не відрізнялася від показників клінічно здорових тварин (табл. 5).

Таблиця 5

Активність ензимів у сироватці крові коней хворих на астму ускладнену МКД

\begin{tabular}{lcccc}
\hline \multicolumn{1}{c}{ Показники } & АсАТ, од/л & АлАТ, од/л & ЛФ, од/л & ГГТП, од/л \\
\hline \multirow{2}{*}{ Клінічно здорові коні } & $270,1 \pm 17,04$ & $6,1 \pm 0,88$ & $121,5 \pm 14,97$ & $12,1 \pm 0,60$ \\
& $196,0-402,0$ & $4,0-14,0$ & $68,0-273,0$ & $10,0-15,0$ \\
Хворі коні & $338,8 \pm 17,50^{*}$ & $8,2 \pm 0,71$ & $181,5 \pm 18,27^{*}$ & $19,7 \pm 2,45^{* *}$ \\
\multirow{2}{*}{ Після лікування } & $269,0-436,0$ & $5,0-11,0$ & $98,0-309,0$ & $12,0-29,0$ \\
& $288,7 \pm 15,31^{\circ}$ & $7,5 \pm 0,76$ & $127,4 \pm 14,45^{\circ}$ & $13,4 \pm 1,67^{\circ}$ \\
& $227,0-412,0$ & $4,0-11,0$ & $94,0-263,0$ & $11,0-27,0$ \\
\hline
\end{tabular}

У подальшому дослідженні ми використали показники активності екскреторних ензимів (ЛФ, ГГТП) 3 метою виявлення у хворих коней коморбідної патологіï. Характер виявлених змін свідчить, що у хворих коней 3 поєднаним перебігом астми і МКД в сироватці крові відбувається вірогідне зростання активності ЛФ та ГГТП (Р < 0,05-0,01; табл. 5) порівняно 3 клінічно здоровими тваринами, що може бути проявом синдрому “взаємного обтяження” при одночасному впливі двох патологій. Отже, у коней, хворих на астму, ускладнену МКД, розвивається поєднана (коморбідна) патологія, за якої уражаються також клітини печінки і виникають передумови до прогресування патологічного процесу (Pasiieshvili et al., 2015).

3 метою аналізу впливу астми на міокард нами проаналізовано активність кардіоспецифічних ензимів. Отримані результати показали, що в сироватці крові хворих коней зростала активність КК та ЛДГ заг. (Р < 0,05), що, очевидно, відбувалося за рахунок серцевих ізоферментів. Це підтверджується вірогідним підвищенням активності КК-МВ на 27,0\% (P < $0,05)$ та ЛДГ-1 на $14,7 \%(\mathrm{P}<0,05)$ порівняно з клінічно здоровими тваринами (табл. 6). 
Таблиця 6

Активність кардіоспецифічних ензимів у крові коней хворих на астму ускладнену МКд

\begin{tabular}{ccccc}
\hline Показники & КК, од/л & КК-МВ, од/л & ЛДГ, од/л & ЛДГ-1, од/л \\
\hline Клінічно здорові & $184,6 \pm 12,79$ & $247,6 \pm 15,57$ & $593,6 \pm 22,66$ & $260,9 \pm 11,99$ \\
коні & $136,0-260,0$ & $194,0-338,0$ & $450,0-680,0$ & $176,0-313,0$ \\
Хворі коні & $234,4 \pm 15,30^{*}$ & $312,5 \pm 16,64^{*}$ & $699,4 \pm 27,85^{*}$ & $299,3 \pm 11,91^{*}$ \\
\multirow{2}{*}{ Після лікування } & $173,0-322,0$ & $226,0-405,0$ & $575,0-911,0$ & $249,0-365,0$ \\
& $204,5 \pm 13,75$ & $263,7 \pm 14,91^{\circ}$ & $614,0 \pm 21,25^{\circ}$ & $270,3 \pm 12,75$ \\
\hline
\end{tabular}

Отже, вивільнення КК-МВ та ЛДГ-1 з цитозольного пулу кардіоміоцитів може вказувати на пошкодження клітин міокарда та розвиток міокардіодистpoфiï (Kratz et al., 2002).

Розвиток у коней, хворих на астму, міокардіодистрофії може забезпечувати тяжкість перебігу основного захворювання та впливати на його прогноз (Tkach, 2008; Targher et al., 2010).

Спираючись на дані численних клінічних досліджень, в науковій і практичній медицині все частіше повідомляється про поєднаний перебіг широко поширених захворювань, зокрема бронхіальної астми (БА) i метаболічного синдрому (MC) (Budnevskij, 2005; Budnevskij et al., 2010; Sysoeva et al., 2011). Варто також зазначити, що підкреслюється наявність при цих нозологічних формах складних, численних патогенетичних зв'язків, які в більшості випадків призво- дять до формування феномену взаємообтяження, що обмежує досягнення контрольованого перебігу БА, 3 одного боку, і підвищує ризик розвитку захворювань серцево-судинної системи - 3 іншого (Tribunceva et al., 2012; Ermolova and Budnevskij, 2013).

За останні роки накопичені численні, але розрізнені і суперечливі факти, що свідчать про участь мінералів і мікроелементів в різних ланках патогенезу алергії (WHO, 1996). Водночас число клінічних досліджень, присвячених обміну макро- i мікроелементів при бронхіальній астмі в коней, обмежена.

У коней, хворих на астму, ускладнену МКД, вміст загального кальцію, неорганічного фосфору, натрію, калію та феруму в сироватці крові не відрізнявся статистично від показників клінічно здорових тварин. Однак нами встановлено вірогідне зниження рівня магнію в крові хворих коней (Р $<0,05$; табл. 7).

\section{Таблиця 7}

Макроелементний статус коней хворих на астму ускладнену МКД

\begin{tabular}{lccc}
\hline \multicolumn{1}{c}{ Показники } & Клінічно здорові коні & Хворі коні & Після лікування \\
\hline \multirow{2}{*}{$\mathrm{Ca}$, ммоль/л } & $2,85 \pm 0,028$ & $2,93 \pm 0,029$ & $2,88 \pm 0,030$ \\
& $2,69-3,00$ & $2,84-3,07$ & $2,77-3,09$ \\
$\mathrm{Pn}$, ммоль/л & $0,92 \pm 0,068$ & $0,94 \pm 0,091$ & $0,91 \pm 0,061$ \\
& $0,70-1,33$ & $0,72-1,67$ & $0,69-1,20$ \\
$\mathrm{Mg}$, ммоль/л & $0,79 \pm 0,013$ & $0,74 \pm 0,014 *$ & $0,79 \pm 0,016^{\circ}$ \\
& $0,69-0,83$ & $0,65-0,80$ & $0,67-0,82$ \\
$\mathrm{Na}$, ммоль/л & $129,1 \pm 4,13$ & $128,0 \pm 3,03$ & $130,4 \pm 3,71$ \\
& $114,1-153,6$ & $112,2-142,0$ & $121,2-150,7$ \\
$\mathrm{~K}$, ммоль/л & $3,7 \pm 0,13$ & $3,8 \pm 0,12$ & $3,9 \pm 0,17$ \\
\multirow{2}{*}{$\mathrm{Fe,} \mathrm{мкмоль/л}$} & $3,19-4,30$ & $3,16-4,41$ & $3,20-4,57$ \\
& $30,7 \pm 1,26$ & $29,3 \pm 1,32$ & $31,0 \pm 1,34$ \\
\end{tabular}

За бронхіальної астми в результаті гіпоксичного спазму легеневих судин збільшується легеневий опір, що зумовлює додаткове навантаження на серце, i ще більше поглиблення синдрому взаємного обтяження (Gavrisjuk, 2000).

За даними спеціалізованої літератури відомо, що порушення газового складу крові - гіпоксемія і гіперкапнія (в разі гіпервентиляції легень - гіпокапнія) є важливими показниками недостатності зовнішнього дихання. Гіпервентиляція веде до підвищення рО2 і зниження рСО2 в альвеолярному повітрі. Відповідно в артеріальній крові знижується рСО2 (гіпокапнія), що супроводжується газовим алкалозом (AguileraTejero et al., 2000).

Порушення рівноваги між вентиляцією і перфузією легень призводить до зниження рО2, яке може спостерігатися навіть у період між астматичними нападами. pO2 під час нападу бронхіальної астми знижується пропорційно ступеню обструкції бронхів. рСО2 спочатку теж знижується, проте згодом підвищується. Так, при легких нападах зазвичай спостерігається гіпервентиляція, яка призводить до зниження рСО2. При важких приступах частіше розвивається гіповентиляція, показником якої служить збільшення рСО2. Нормальний або підвищений рівень рСО2 під час нападу бронхіальної астми свідчить про виражену обструкцію бронхів і необхідність негайного лікування під постійним контролем газів артеріальної крові (Effros and Swenson, 2010).

3 метою оцінки впливу гіпоксії на морфофункціональний стан мукоциліарної системи у хворих на астму коней, ускладнену МКД, були вивчені показники газотранспортної функції в периферичній крові. Дослідження показали, що у коней, хворих на астму, 
ускладнену МКД, має місце вірогідне зниження рівня pCO2 (P $<0,01$; табл. 8). Також у хворих коней в периферичній артеріальній крові встановлено тенденцію до зниження $\mathrm{pO} 2$ та до підвищення $\mathrm{pH}$ (табл. 8), що може свідчити про розвиток субкомпенсованого дихального алкалозу (Maksymovych et al., 2017). Такі зміни в слизовій оболонці призводять до пригнічення активності мукоциліарного апарату бронхіальних шляхів (Nadtochij, 2015).

Результати досліджень показали, що після проведеного лікування в коней відновлювалася працездатність, не реєструвалися або ставали менш виражени- ми ознаки втомлюваності під час фізичного навантаження.

Лікування позитивно впливало на перебіг респіраторного синдрому, оскільки в коней не реєстрували нападів кашлю, носові виділення та задишка були відсутніми. Лише в 1 тварин (10\%) діагностували спорадичний кашель і ще в 1 (10\%) погану переносимість фізичного навантаження та тривалий час відновлення після роботи. При аускультації легень патологічних дихальних шумів (крепітація, хрипи) не виявляли.

\section{Таблиця 8}

Показники кислотно-основного балансу артеріальної крові коней, хворих на астму, ускладнену МКД

\begin{tabular}{cccc}
\hline Показники & $\mathrm{pH}$ & $\mathrm{pO}_{2}$ & $\mathrm{pCO}_{2}$ \\
\hline \multirow{2}{*}{ Клінічно здорові коні } & $7,46 \pm 0,004$ & $99,3 \pm 3,51$ & $45,3 \pm 0,53$ \\
& $7,45-7,48$ & $84-125$ & $43-49$ \\
Хворі коні & $7,47 \pm 0,009$ & $92,2 \pm 2,79$ & $41,4 \pm 0,87 * *$ \\
& $7,44-7,54$ & $81-109$ & $37-46$ \\
Після лікування & $7,46 \pm 0,006$ & $97,9 \pm 2,91$ & $44,5 \pm 0,60^{\circ}$ \\
& $7,43-7,48$ & $85-117$ & $41-48$ \\
\hline
\end{tabular}

Після лікування коней в змивах, отриманих за допомогою БАЛ, зменшувалася кількість нейтрофілів в середньому до 9,7 $\pm 1,75 \%(\mathrm{P}<0,001)$ порівняно 3 долікувальним періодом.

За результатами електрокардіографії, проведеної в коней після лікування встановлено, що у 7 тварин (70\%) ритм був синусовий, у 1 тварини (10\%) реєстрували синусову аритмію, в 1 (10\%) - тахікардію, в 1 (10\%) - атріовентрикулярну (АВ) блокаду II ступеня (30\% від дослідної групи коней).

За даними ехокардіографічного дослідження в динаміці спостереження встановили позитивний вплив лікування на частоту клапанної регургітації: з 20 до $10 \%$ зменшувалася регургітація мітрального клапана та клапанів аорти, відповідно.

У коней за астми, ускладненої МКД, лікування сприяло усуненню гіпоксії, оскільки в крові вірогідно зменшувалася кількість еритроцитів $(\mathrm{P}<0,05)$, вміст гемоглобіну ( $\mathrm{P}<0,01)$, гематокрит $(\mathrm{P}<0,05)$, середній об'єм еритроцита $(\mathrm{P}<0,001)$ та середній вміст гемоглобіну в еритроциті (Р $<0,001)$, тоді як ширина розподілу еритроцитів за об'ємом зростала (Р < 0,01; табл. 1).

Проведене лікування хворих коней сприяло зменшенню активності запального процесу в дихальних шляхах, оскільки в крові знижувалася кількість лейкоцитів (Р $<0,001)$, паличкоядерних $(\mathrm{P}<0,01)$ та сегментоядерних (P < 0,01) нейтрофілів, а кількість моноцитів мала тенденцію до зниження. Водночас збільшення кількості лімфоцитів у крові коней після лікування (Р < 0,001) може свідчити про відновлення захисних механізмів організму тварин (табл. 2).

Оскільки на перебіг запального процесу в дихальних шляхах коней, хворих на астму, ускладнену МКД, разом $з$ іншими запальними типами клітин можуть впливати також тромбоцити (Kornerup and Page, 2007), тому вірогідне $(\mathrm{P}<0,05)$ збільшення показників тромбопоезу (кількість тромбоцитів і тромбокрит), може свідчити про позитивну динаміку в лікуванні (табл. 3).

Результатом зменшення запальної реакції в дихальних шляхах коней після лікування було зниження в сироватці крові вмісту загального протеїну ( $<0,05$; табл. 4). Водночас вміст альбумінів у крові коней не відрізнявся від показників порівняно з долікувальним періодом. Отже, лікування не мало негативного впливу на білоксинтезувальну функцію печінки.

Тенденція до зниження концентрації загального білірубіну в сироватці крові коней після лікування, очевидно, пов'язана із покращенням пігментної функції печінки (табл. 4).

Після проведеного лікування в сироватці крові коней встановлено тенденцію до підвищення вмісту глюкози (табл. 4). Водночас концентрація сечовини та креатиніну в крові після лікування не відрізнялися статистично від показників долікувального періоду (табл. 4).

При аналізі показників активності ензимів у коней, хворих на астму, ускладнену МКД, після лікування показали відмінності. Так, активність АсАТ в сироватці крові вірогідно знижувалася (Р < 0,05; табл. 5), що, очевидно пов'язано із стабілізацією мембран клітин, де ензим локалізується. Активність АлАТ в крові коней після лікування також мала тенденцію до зниження (табл. 5).

Згідно $з$ результатами наших досліджень у коней після лікування знижувалася активність ЛФ $(\mathrm{P}<0,05)$ та ГГТП (Р < 0,05; табл. 5), що підтверджує ефективність лікувальних заходів за перебігу коморбідної (кардіо-пульмональної) патології.

Після лікування у сироватці крові коней встановлено тенденцію до зниження активності загальної КК на 12,7\% порівняно 3 долікувальним періодом. Водночас активність кардіоспецифічного ензиму КК-МВ знижувалася вірогідно (Р < 0,05; табл. 6). Проведене лікування сприяло зниженню активності загальної 
ЛДГ (Р < 0,05), тимчасом як активність кардіоспецифічного ензиму ЛДГ-1 знижувалася на 9,7\% (табл. 6). Отже, лікування сприяло відновленню та стабілізації мембран кардіоміоцитів у коней, хворих на астму, ускладнену МКД.

У коней з поєднаним перебігом астми і МКД після лікування не встановлено вірогідної різниці у показниках обміну макроелементів і електролітів за вмістом загального кальцію, неорганічного фосфору, феруму, натрію та калію. Однак в сироватці крові вірогідно зростав вміст магнію ( $<0,05$; табл. 7).

Аналіз показників газового складу крові показав, що після лікування коней, хворих на астму, ускладнену МКД встановлено, що парціальний тиск вуглекислого газу $\left(\mathrm{pCO}_{2}\right)$ в артеріальній крові вірогідно зростав $(\mathrm{P}<0,05)$ (табл. 8). Водночас, знижувався водневий показник $(\mathrm{pH})$ та підвищувався парціальний тиск кисню $\left(\mathrm{pO}_{2}\right.$; табл. 8).

Отже, результатом прогресування патологічного процесу в бронхолегеневій системі за астми в коней можуть формуватися ускладнення 3 боку серцевосудинної системи у формі міокардіодистрофії.

При поєднаній (коморбідній) кардіопульмональній патології застосування комплексної схеми лікування сприяє зменшенню гіпоксії та запального процесу в дихальних шляхах коней, відновленню мембран кардіоміоцитів і газо-транспортної функції крові.

\section{Висновки}

1. При коморбідній (кардіо-пульмональній) патології у коней, хворих на астму, розвиваються симптомокомплекс обструкції дихальних шляхів, морфофункціональні зміни еритроцитарної системи, порушення газотранспортної функції крові, підвищення проникності клітинних мембран, що призводить до ускладнень у формі міокардіодистрофії та розвитку серцевої недостатності.

2. Застосування комплексної схеми лікування коней, хворих на астму, ускладнену МКД, сприяло зменшенню приступів респіраторної дисфункції та симптомів серцевої недостатності, зменшенню частоти виникнення аритмій та клапанної регургітації, зменшенню кількості нейтрофілів у змивах БАЛ, зниженню показників, що характерні для тканинної гіпоксії (зменшення кількості еритроцитів, вмісту гемоглобіну, величини гематокриту, середнього об'єму еритроцита та середнього вмісту гемоглобіну в еритроциті), усуненню запального процесу в дихальних шляхах (зменшення кількості лейкоцитів, паличкоядерних i сегментоядерних нейтрофілів), зниженню показників, що характеризують цілісність мембран кардіоміоцитів (зниження активності КК, КК-МВ, ЛДГ, ЛДГ-1), відновленню дифузної здатності легень (зниження рН та підвищення рО2 і рСО2 крові).

3. Встановлено механізм позитивного впливу препаратів, які використовувалися для лікування коней, хворих на астму, ускладнену МКД, що досягається за рахунок кардіометаболічного (цитопротективного) ефекту й антигіпоксичної здатності поліпшувати дифузію газів через альвеолярно-капілярну мембрану.
Це, з одного боку, поліпшує процеси метаболізму в міокарді і, відповідно, зменшує прояви серцевої недостатності, а 3 іншого - зменшує гіпоксію та прояви дихальної недостатності (респіраторної дисфункціі), як одного з центральних патогенетичних механізмів формування кардіо-респіраторної коморбідності.

Перспективи подальших досліджень є вивчення впливу пероральних форм Омега-3 поліненасичених жирних кислот і засобів метаболічної терапії у комплексній схемі лікування коней за коморбідної (кардіо-пульмональної) патології.

\section{References}

Maksymovych, I., Siwińska, N., Słowikowska, M., Żak, A., \& Niedźwiedź, A. (2016). Postać ciężka astmy koni - nowa nazwa znanej choroby. Weterynaria w terenie, 3, 74-79.

Sánchez, A., Couëtil, L.L., Ward, M.P., \& Clark, S.P. (2005). Effect of airway disease on blood gas exchange in racehorses. Journal of Veterinary Internal Medicine, 19(1), 87-92. https://www.ncbi.nlm.nih. gov/pubmed/15715053.

Niedźwiedź, A., Nicpoń, J., \& Różycki, P. (2006). Pathogenesis, diagnosis and treatment of Recurrent Equine Airway Obstruction. Med. Weter., 62(5), 512515.

Pasławska, U., Nicpoń, J., \& Noszczyk-Nowak, A. (2008). Wybrane metody klinicznej diagnostyki różnicowej przewlekłej niewydolności oddechowej u koni. Magazyn weterynaryjny, 17(2), 118-119.

Maksymovych, I.A. (2015). Retsydyvuiucha obstruktsiia dykhalnykh shliakhiv u konei: poshyrennia, etiolohiia ta patohenez. Naukovyi visnyk Lvivskoho natsionalnoho universytetu veterynarnoi medytsyny ta biotekhnolohii imeni S.Z. Gzhytskoho, 17, 2(62), 137-142. http://nbuv.gov.ua/UJRN/nvlnu_2015_17_2_31 (in Ukrainian).

Palomo, L., Rubio, C., \& Gérvas, J. (2006). The comorbidity in primary care. Gac. Sanit., 20(1), 182191. https://www.ncbi.nlm.nih.gov/pubmed/16539981.

Ollivier, R., Donal, E., Delaval, P., Daubert, J.C., \& Mabo, P. (2007). Beta-blocker prescription and chronic obstructive pulmonary disease. Ann. Cardiol. Angeiol., 56(5), 231-236.

Falk, J.A., Kadiev, S., Criner, G.J., Scharf, S.M., Minai, O.A., \& Diaz, P. (2008). Cardiac disease in chronic obstructive pulmonary disease. Proc. Am. Thorac. Soc., 5(4), 543-548. doi: 10.1513/pats.200708-142ET.

Avdeev, S.N., \& Bajmakanova, G.E. (2008). HOBL i serdechno-sosudistye zabolevanija: mehanizmy associacii. Pul'monologija, 1, 5-13 (in Russian).

Ambrosino, N., \& Simonds, A. (2007). The clinical management in extremely severe COPD. Respir. Med., 101(8), 1613-1624. doi: 10.1016/j.rmed.2007.02.011.

Korzh, A.N. (2008). Serdechno-sosudistaja patologija u bol'nyh hronicheskim obstruktivnym zabolevaniem legkih. Mezhdunarodnyj medicinskij zhurnal, 2, 4146 (in Russian).

Chuchalin, A.G. (2008). Hronicheskoe obstruktivnoe zabolevanie legkih i soputstvujushhie zabolevanija. Ter. arhiv, 8, 45-50 (in Russian). 
Maksymovych, I.A. (2017). Hematolohichnyi status konei za astmatychnoho syndromu. Nauk. visnyk veterynarnoi medytsyny, 1(133), 68-76 (in Ukrainian).

Chuchalin, A.G. (2008). Hronicheskoe obstruktivnoe zabolevanie legkih i soputstvujushhie zabolevanija. Zdorov'ja Ukrainy, 7, 37-39 (in Russian).

Capko, L.P., Afanas'ev, S.A., \& Maksimov, I.V. (2016). Perspektivy metabolicheskoj terapii pri patologii serdca. Sibirskij medicinskij zhurnal, 31(4), 7-12. doi: 10.29001/2073-8552-2016-31-4-7-12 (in Russian).

Duvivier, D.H., Bayly, W.M., Votion, D., Vandenput, S., Farnir, F., \& Lekeux, P. (1999). Effects of inhaled dry powder ipratropium bromide on recovery from exercise of horses with COPD. Equine Vet. J., 31(1), 20-24. https://www.ncbi.nlm.nih.gov/pubmed/9952325.

Duvivier, D.H., Votion, D., Vandenput, S., Art, T., \& Lekeux, P. (1997). Airway response of horses with COPD to dry powder inhalation of ipratropium bromide. Vet. J., 154(2), 149-153. https://www.ncbi.nlm.nih.gov/pubmed/9308401.

Robinson, N.E., Jackson, C., Jefcoat, A., Berney, C., Peroni, D., \& Derksen, F.J. (2002). Efficacy of three corticosteroids for the treatment of recurrent airway obstruction (heaves). Equine Vet. J., 34(1), 17-22. https://www.ncbi.nlm.nih.gov/pubmed/11817547.

Amosova, E.N. (2000). Metabolicheskaja terapija povrezhdenija miokarda, obuslovlennogo ishemiej: novyj podhod $\mathrm{k}$ lecheniju ishemicheskoj bolezni serdca i serdechnoj nedostatochnosti. Ukr. kardiol. zhurn., 4, 85-92 (in Russian).

Schraeder, C., Dworak, D., Stoll, J.F., Kucera, C., Waldschmidt, V., \& Dworak, M.P. (2005). Managing elders with comorbidities. J. Ambul. Care Manage, 28(3), 201-209. https://www.ncbi.nlm.nih.gov/ pubmed/15968212.

Sin, D.D., Anthonisen, N.R., Soriano, J.B., \& Agusi, A.G. (2006). Mortality in COPD: role of comorbidities. Eur. Respir. J., 28(6), 1245-1257. doi: 10.1183/09031936.00133805.

Boudestein, L.C., Rutten, F.H., Cramer, M.J., Lammers, J.W., \& Hoes, A.W. (2009). The impact of concurrent heart failure on prognosis in patients with chronic obstructive pulmonary disease. Eur. J. Heart Fail., 11(12), 1182-1188. doi: 10.1093/eurjhf/hfp148.

Ihnatenko, H.A., Mukhin, I.V., Faierman, A.O., Pola, M.K., Taktashov, H.S., Honcharov, O.M., Rybalko, H.S., \& Volodkina, N.O. (2011). Vplyv Mildrokardu na morfofunktsionalnyi stan kardiorespiratornoi systemy $u$ khvorykh na khronichnu sertsevu nedostatnist iz suputnim khronichnym obstruktyvnym zakhvoriuvanniam lehen. News of medicine and pharmacy, 13-14, 376-377 (in Ukrainian).

Gerber, V., Lindberg, A., Berney, C., Robinson, N.E. (2004). Airway mucus in recurrent airway obstruction-short-term response to environmental challenge. J Vet Intern Med., 18(1), 92-97. https://www.ncbi.nlm.nih.gov/pubmed/14765737.

Glazova, T.G., Ryvkin, A.I., \& Pobedinskaja, N.S. (2012). Morfofunkcional'noe sostojanie jeritrocitov pri persistirujushhem techenii bronhial'noj astmy u detej. Pediatrija, https://pediatriajournal.ru/archive?show=321\&section $=3365$ (in Russian).

Nowak, W., Potkański, A., Zachwieja, A., Szulc, T., Wylegała, S., \& Werwińska, K. (2005). Effect of herb extracts on serum immunoglobulins and calf-rearing results. Med Weter., 61, 1049-1054.

Pitchford, S.C., Riffo-Vasquez, Y., Sousa, A., Momi, S., Gresele, P., Spina, D., \& Page, C.P. (2004). Platelets are necessary for airway wall remodeling in a murine model of chronic allergic inflammation. Blood, 103(2), 639-647. doi: 10.1182/blood-2003-05-1707.

Singh, T.P., Nigam, A.K., Gupta, A.K., \& Singh, B. (2011). Cardiac Biomarkers: When to Test? Physician Perspective. JIACM, 12(2), 117-121. http://medind.nic.in/jac/t11/i2/jact11i2p117.pdf.

Pasiieshvili, L.M., Zhelezniakova, N.M., \& Pasiieshvili, T.M. (2015). Kliniko-patohenetychni osoblyvosti perebihu nealkoholnoi zhyrovoi khvoroby pechinky u khvorykh na bronkhialnu astmu ta ozhyrinnia. Hastroenterolohiia, 4, 47-52. http://nbuv.gov.ua/ UJRN/gastro_2015_4_9 (in Ukrainian).

Kratz, A., Lewandrowski, K.B., Siegel, A.J., Chun, K.Y., Flood, J.G., Van Cott, E.M., \& Lee-Lewandrowski, E. (2002). Effect of marathon running on hematologic and biochemical laboratory parameters, including cardiac markers. Am. J. Clin. Pathol., 118(6), 856863. doi: 10.1309/14TY-2TDJ-1X0Y-1V6V.

Tkach, S.M. (2008). Sistemnye podhody k diagnostike i lecheniju zhirovoj bolezni pecheni. Zdorovia Ukrainy, 22, 64-65 (in Russian).

Targher, G., Day, C., \& Bonora, E. (2010). Risk of cardiovascular disease in patients with nonalcoholic fatty liver disease. N. Engl. J. Med., 363(14), 13411350. doi: 10.1056/NEJMra0912063.

Budnevskij, A.V. (2005). Sistemnyj podhod k izucheniju psihonejroimmunologicheskih vzaimodejstvij pri bronhial'noj astme. Sistemnyj analiz i upravlenie v biomedicinskih sistemah, 4(1), 20-23 (in Russian).

Budnevskij, A.V., Burlachuk, V.T., \& Olysheva, N. (2010). Terapevticheskie podhody k kontrolju vospalenija na urovne melkih bronhov pri bronhial'noj astme. Rossijskij allergologicheskij zhurnal, 4, 85-94 (in Russian).

Sysoeva, M.S., Solov'eva, A.V., Nikiforov, A.A., \& Rakita, D.R. (2011). Vlijanie nalichija metabolicheskogo sindroma na klinicheskoe techenie bronhial'noj astmy. Rossijskij mediko-biologicheskij vestnik imeni akademika I.P. Pavlova, 4, 100-105 (in Russian).

Ermolova, A.V., \& Budnevskij, A.V. (2013). Bronhial'naja astma i metabolicheskij sindrom: vozmozhnosti dostizhenija kontrolja nad zabolevaniem i uluchshenija kachestva zhizni. Vrach-aspirant, 61(6.2), 319-325. http://vrach-aspirant.ru/articles/ pulmonology/13469/ (in Russian).

Tribunceva, L.V., Budnevskij, A.V., \& Razvorotnev, A.V. (2012). Sistemnyj podhod k upravleniju terapiej bol'nyh bronhial'noj astmoj. Vrach-aspirant, 1.2 (5), 338-342. http://vrach-aspirant.ru/articles/ pulmonology/12010/ (in Russian). 
WHO (1996). Trace elements in human nutrition and healt. Geneva, XVIII. https://www.who.int/nutrition/ publications/micronutrients/9241561734/en.

Gavrisjuk, V.K. (2000). Narushenija serdechno-sosudistoj sistemy u bol'nyh bronhial'noj astmoj. Ukr. pul'mon. zhurn., 2, 31-32 (in Russian).

Aguilera-Tejero, E., Estepa, J.C., Lopez, I., Bas, S., Mayer-Valor, R., \& Rodriguez, M. (2000). Quantitative analysis of acid-base balance in show jumpers before and after exercise. Res. Vet. Sci., 68(2), 103-108. doi: 10.1053/rvsc.1999.0341.

Effros, R.M., \& Swenson, E.R. (2010). Acid_base balance. Mason R.J. et al. Murray \& Nädel's Textbook of Respiratory Medicine. 5th ed. Philadelphia.
Maksymovych, I., Niedźwiedź, A., Leno, M., \& Slivinskaya, L. (2017). Biochemical parameters and acid-base balanse of blood of horses with asthma syndrome. Scientific Messenger LNUVMB, 19(82), 205-211. https://nvlvet.com.ua/index.php/journal/ article/view/1367.

Nadtochij, E.V. (2015). Povrezhdajushhee vlijanie gipoksii na sostojanie mukociliarnogo apparata u bol'nyh bronhial'noj astmoj. Bjulleten' fiziologii i patologii dyhanija, 58, 30-33. https://elibrary.ru/item.asp?id=25013403 (in Russian).

Kornerup, K.N., \& Page, C.P. (2007). The role of platelets in the pathophysiology of asthma. Platelets, 18(5), 319-328. doi: 10.1080/09537100701230436. https://www.ncbi.nlm.nih.gov/pubmed/17654302. 